University of Nebraska - Lincoln

DigitalCommons@University of Nebraska - Lincoln

Biological Systems Engineering: Papers and

Publications

Biological Systems Engineering

$7-2021$

\title{
Sensor-based irrigation of maize and soybean in East-Central Nebraska under a sub-humid climate
}

\author{
Jasreman Singh \\ University of Nebraska-Lincoln, jasreman.singh@huskers.unl.edu \\ Derek M. Heeren \\ University of Nebraska-Lincoln, derek.heeren@unl.edu \\ Yufeng Ge \\ University of Nebraska - Lincoln, yge2@unl.edu \\ Geng Bai \\ University of Nebraska-Lincoln, gbai2@unl.edu \\ Christopher M.U. Neale \\ University of Nebraska \& Daugherty Water for Food Global Institute, cneale@nebraska.edu
}

See next page for additional authors

Follow this and additional works at: https://digitalcommons.unl.edu/biosysengfacpub

Part of the Agriculture Commons, and the Bioresource and Agricultural Engineering Commons

Singh, Jasreman; Heeren, Derek M.; Ge, Yufeng; Bai, Geng; Neale, Christopher M.U.; Maguire, Mitchell S.; and Bhatti, Sandeep, "Sensor-based irrigation of maize and soybean in East-Central Nebraska under a subhumid climate" (2021). Biological Systems Engineering: Papers and Publications. 763.

https://digitalcommons.unl.edu/biosysengfacpub/763

This Article is brought to you for free and open access by the Biological Systems Engineering at DigitalCommons@University of Nebraska - Lincoln. It has been accepted for inclusion in Biological Systems Engineering: Papers and Publications by an authorized administrator of DigitalCommons@University of Nebraska Lincoln. 


\section{Authors}

Jasreman Singh, Derek M. Heeren, Yufeng Ge, Geng Bai, Christopher M.U. Neale, Mitchell S. Maguire, and Sandeep Bhatti 


\title{
An ASABE Meeting Presentation
}

DOI: https://doi.org/10.13031/aim.21001044

2950 Niles Road, St. Joseph, MI 49085-9659, USA

Paper Number: 21001044

269.429.0300 fax 269.429.3852 hq@asabe.org www.asabe.org

\section{Sensor-based Irrigation of Maize and Soybean in East-Central Nebraska under a Sub-Humid Climate}

\author{
Jasreman Singh ${ }^{1}$, Derek M. Heeren ${ }^{1}$, Yufeng Ge ${ }^{1}$, Geng Bai ${ }^{1}$, Christopher M. U. Neale ${ }^{1,2}$, Mitchell \\ S. Maguire ${ }^{1}$, Sandeep Bhatti ${ }^{1}$ \\ ${ }^{1}$ Department of Biological Systems Engineering, University of Nebraska-Lincoln \\ ${ }^{2}$ Daugherty Water for Food Global Institute at the University of Nebraska \\ Written for presentation at the \\ 2021 Annual International Meeting \\ ASABE Virtual and On Demand \\ July 12-16, 2021
}

\begin{abstract}
The ever increasing pressure on the water resources in Nebraska and other irrigated agricultural areas require innovations and solutions for the governance of water allocation. This study proposes the use of sensor-based method for irrigation which has the potential to improve irrigation water use efficiency (IWUE). Practical methods and algorithms for creating irrigation prescriptions have become vital for the adoption of precision irrigation. A decision support system (DSS) for uniform irrigation was evaluated during 2020 growing season in a sub-humid region. The DSS was managed using soil water and plant feedback. In field practice, a sensor node station comprising of soil water content sensors and infrared thermometer (IRT) was installed in maize and soybean. Root zone water depletion $\left(D_{r w}\right)$, and crop water stress index (CWSI) served as the inputs for soil water, and plant feedback, respectively. The timing and depth of irrigation was determined using the DSS. The results of the sensor-based DSS treatment were compared to conventional treatment (managed by a crop consultant) and rainfed (no-irrigation) treatment. Test results for maize and soybean indicated that there was no significant difference in crop yield between sensor-based and conventional treatments. However, the sensor-based DSS treatment witnessed higher IWUE for both maize and soybean. The observed yield for rainfed treatment was significantly lower than the irrigated treatments in maize and soybean. There is a great potential for the use of this DSS system for uniform irrigation in humid and sub-humid regions and future studies are required for the adoption of this technology.
\end{abstract}

Keywords. Crop Water Stress Index, Decision Support System, Irrigation Water Use Efficiency, Root Zone Water Depletion, Sub-Humid Environment, Uniform Irrigation.

\section{INTRODUCTION}

Irrigated agriculture is the primary consumer of freshwater in the U.S., accounting for $80-90$ per cent of the nation's consumption of water (Schaible and Aillery, 2012). The number of farms irrigating and the amount of land irrigated increased by $1.1 \%$ between 2013 and 2018 (USDA NASS, 2018). The state of Nebraska has largest share of irrigated area with 8.6 million acres of land under irrigation (Eisenhauer et al., 2021). Though irrigation is essential for crop production in semi-arid and arid regions, irrigated area has increased rapidly in humid and sub-humid areas recently. It is because with the supplemental irrigation, crop yields attain around $80 \%$ of the potential yield in humid and sub-humid areas whereas the

The authors are solely responsible for the content of this meeting presentation. The presentation does not necessarily reflect the official position of the American Society of Agricultural and Biological Engineers (ASABE), and its printing and distribution does not constitute an endorsement of views which may be expressed. Meeting presentations are not subject to the formal peer review process by ASABE editorial committees; therefore, they are not to be presented as refereed publications. Publish your paper in our journal after successfully completing the peer review process. See www.asabe.org/JournalSubmission for details. Citation of this work should state that it is from an ASABE meeting paper. EXAMPLE: Author's Last Name, Initials. 2021. Title of presentation. ASABE Paper No. ---. St. Joseph, MI.: ASABE. For information about securing permission to reprint or reproduce a meeting presentation, please contact ASABE at www.asabe.org/copyright (2950 Niles Road, St. Joseph, MI 49085-9659 USA). 
rainfed crops attain around 50\% of the potential yield (Lobell et al., 2009). The farmers and producers have been relying on amount and timing of irrigation applications increasingly to ensure adequate yields and reduce production risks.

Nebraska has over one hundred thousand active irrigation wells and every decade ten thousand wells are added; this is increasing the pressure on the freshwater resources. Even though the ground water levels in many parts of Nebraska are generally stable, the total water stored in the High Plains aquifer, which encompasses major parts of Kansas, Colorado, Oklahoma, and Texas, has been declining (Steward and Allen, 2016). The optimum utilization of water in irrigated agriculture is essential for the sustainable use of freshwater resources. In order to address this context, estimation of indicators of water use and efficiency for the implementation of benchmarking analysis is required.

Precision agricultural technologies can apply irrigation water within the field to account for variability in soil and plant characteristics, and can potentially increase the crop water productivity (Evett et al., 2020a). Most of the studies on precision irrigation focused on development of a hardware and software system to precisely deliver a certain amount of water at certain timing within a field (Adeyemi et al., 2017; Evett et al., 2020b; Harun et al., 2015; Kamienski et al., 2019; Khriji et al., 2014; Vories et al., 2020). Although sprinkler irrigation systems equipped with precision irrigation control are now commercially available, effective methods to create prescriptions have been an ongoing area of research for the development and adoption of precision agriculture technologies.

Irrigation management could potentially be improved by better informing the timing and depth of irrigation application, which will eventually reduce the likelihood of excessive or insufficient irrigation. The most commonly used method for irrigation scheduling is to determine the soil water status in the root zone and apply water if there is insufficient water for the plants (Evett and Parkin, 2005). Recently developed electromagnetic sensors are being widely used by researchers and producers to schedule irrigation. Electromagnetic sensors, such as time-domain reflectometry, electrical capacitance and resistance type, devices have been developed and are being adopted for irrigation scheduling (Datta et al., 2018; Lea-Cox et al., 2018; O'Shaughnessy et al., 2020a; Singh et al., 2018; Sui, 2017). The application of canopy temperature as an indicator of crop water stress is a plant-based method to manage irrigation. Thermal sensing technologies have been used for scheduling irrigation by determining crop water stress index (DeJonge et al., 2015; Gardner et al., 1992; Irmak et al., 2000; Jackson et al., 1981; O'Shaughnessy et al., 2017; Peters and Evett, 2008). Most of the research involving use of the soil water feedback and the plant feedback has been performed in arid and semi-arid areas. It is important to conduct additional research to determine their applicability in more humid environments.

Irrigation management based on soil water and plant feedback could potentially be a good decision support system and result in improved crop water productivity. Various research projects focusing on irrigation management based on the soil water and plant feedback have been conducted (Andrade et al., 2015, 2020; Evett et al., 2020b; O'Shaughnessy et al., 2020b; O'Shaughnessy, Kim, et al., 2020; Stone et al., 2020; Vories et al., 2020). These research projects were conducted using a decision support system, i.e., Irrigation Scheduling Supervisory Control and Data Acquisition (ISSCADA) system which was patented by USDA-ARS team at Bushland, Texas (Evett et al., 2014). The ISSCADA system can control variable rate irrigation (VRI) technology systems. The VRI systems can site-specifically apply irrigation water at variable depths within the field to account for spatial variability. Conventionally, irrigation is applied uniformly which intends to apply equal depth of water to all parts of the field. The current study was conducted using uniform irrigation management based on the soil water and the plant feedback in a sub-humid environment of East-Central Nebraska. Electromagnetic soil water content sensors, and canopy temperature sensors were used to determine the soil water, and plant feedback, respectively. The research was conducted during the 2020 growing season over maize and soybean. The objective of this study was to evaluate the decision support system that used soil water and plant feedback to manage irrigation in comparison with a conventional treatment (irrigation was managed by a producer/agronomist) and a rainfed (control/no-irrigation) treatment.

\section{MATERIALS AND METHODS}

\section{Site and Soil Description}

A field experiment was conducted during 2020 growing season at a research farm located within the University of Nebraska's Eastern Nebraska Research and Extension Center (ENREC) near Mead, Nebraska $\left(41.165^{\circ} \mathrm{N}, 96.430^{\circ} \mathrm{W}\right)$ with maize planted in one section of the field and soybean in another. The field was irrigated with a center pivot (Lindsay Corporation Zimmatic 8500), and the field size was nearly 53 ha. In 2020, the field was planted with the maize in the south half of the field and soybean in the northern half. The crops were planted in rows running approximately east-to-west at 0.76 $\mathrm{m}$ spacing, under no till management along with the residue cover from the previous growing seasons. The two major soil types in the experimental field were silty clay loam and silt loam (Soil Survey Staff, 2020). Further details about the field site, soils, and irrigation system description can be found in Barker et al. (2018) and Bhatti et al. (2020).

\section{Experiment Description}

Stationary sensor node stations were installed in maize and soybean along the crop rows with the set of soil water content sensors under the crop row and the IRT mounted over the crop row for the 2020 growing season (Fig. 1a and 1b). Each 
stationary sensor node station was equipped with three soil water content sensors (MeterEnvironment's GS-1, Pullman, WA), and an infrared radiometer (IRT) sensor (Apogee Instruments SI-111, Logan, UT). The single-sensor soil water probes were installed into the pit walls of $0.15 \mathrm{~m}$ diameter auger-dug pits located directly underneath a single row of soybean/maize at a distance of $0.15 \mathrm{~m}$ from the maize/soybean row. The soil water content probes were inserted at a depth of $0.15 \mathrm{~m}, 0.46$ $\mathrm{m}$, and $0.76 \mathrm{~m}$, respectively with the sensor prongs oriented horizontally in the pit (Fig. 1a). However, the IRT sensor was mounted at a constant height of $2 \mathrm{~m}$ above ground for soybean throughout the growing season (Fig. 1b). The IRTs in maize were mounted on an adjustable mast to account for the changing canopy height and maintained at a height difference of 1 $\mathrm{m}$ between the IRT and canopy top (adjusted every two weeks after tasseling). The IRT was oriented vertically looking downward from Nadir for all the node stations. The output from the sensors were recorded every $15 \mathrm{~min}$ as an average with a sampling frequency of $5 \mathrm{~s}$. All the sensors were installed following the manufacturer recommendations and allowed to acclimate with the surrounding soil and environment prior to the start of the study.

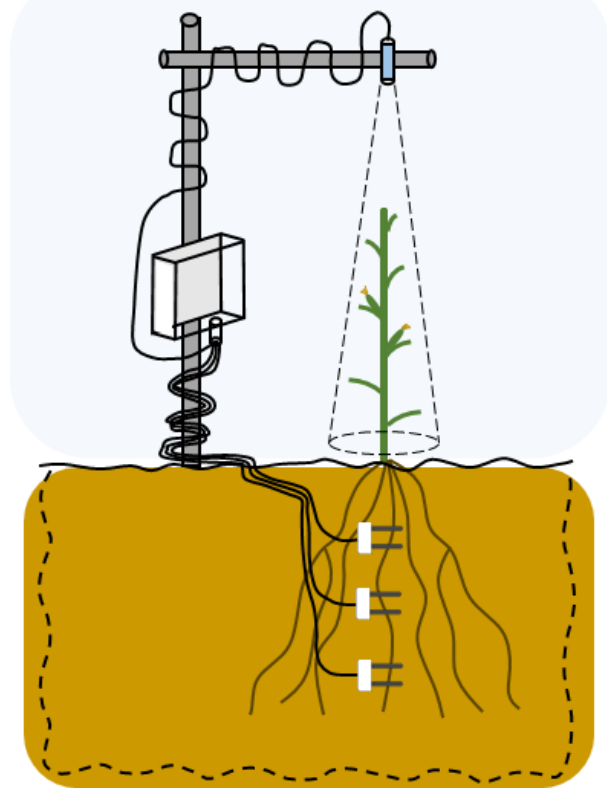

(a)

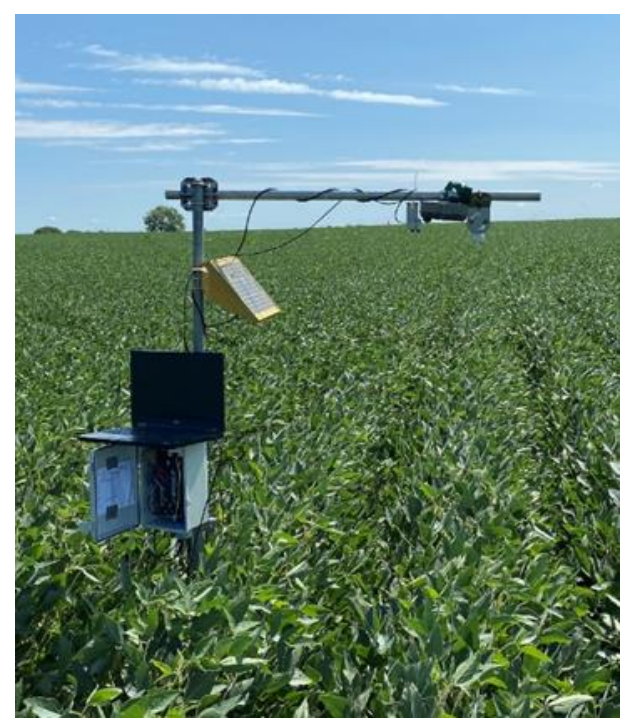

(b)

Figure 1. (a) Illustration of sensor node station comprised of soil water sensors at $0.15 \mathrm{~m}, 0.46 \mathrm{~m}$, and $0.76 \mathrm{~m}$ below the crop row and an infrared radiometer sensing the crop canopy maintained $1 \mathrm{~m}$ over the top of the maize canopy; (b) Sensor node station comprising of infrared radiometer sensor sensing the soybean canopy from $2 \mathrm{~m}$ above the ground.

One sensor node station was installed on the north side and the other on the south side of the field to capture the soil water dynamics and crop canopy status for soybean, and maize, respectively (Fig. 2). The plots were designed along the crop rows. The study included a total of 54 plots: 36 plots in the north and 18 in the south (Fig. 2). The dimensions of the plots were rectangular with length of $\sim 61 \mathrm{~m}$ and width of $\sim 37 \mathrm{~m}$. The treatments were randomized and assigned to the plots. 


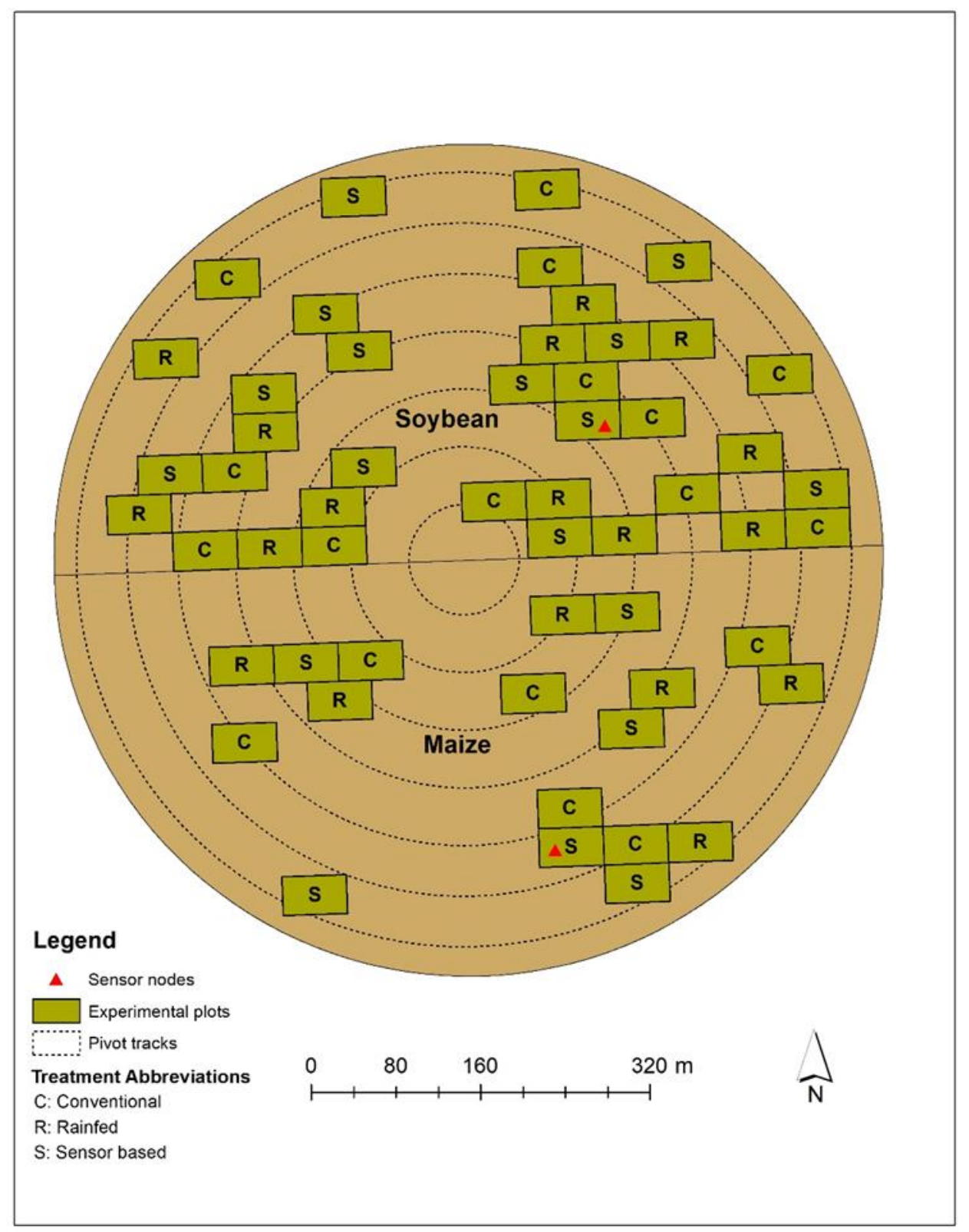

Figure 2. Plot layout of experiment during 2020 growing season. Letters inside plots denote treatments applied (C: Conventional; R: Rainfed; and S: Sensor-based) in 2020. The dotted black lines represent pivot tracks. The sensor node locations in maize and soybean have been marked.

There were three irrigation treatments in both the north and south halves of the field: conventional, rainfed, and sensorbased. A total of 54 plots were equally divided among the three treatments to form a balanced design for both the halves of the field. There were a total of twelve replications dedicated to each treatment on the north half of the field, where soybean was planted. The maize was planted in the south half of the field and a total of six replications were allotted to each treatment. The irrigation in the conventional treatment plots was managed by a professional crop consultant based on experience and visually inspecting the crop canopy and the soil surface. The irrigation for the sensor-based irrigation treatment was managed by the determination of crop water stress index $(C W S I)$ and root zone water depletion $\left(D_{r w}\right)$ by the sensors installed at the stationary sensor node station. One stationary sensor node station was dedicated to maize and soybean. The irrigation for all the sensor-based treatment plots in maize and soybean was managed based on the observed CWSI and $D_{r w}$ for the stationary sensor node stations located in maize and soybean, respectively. A total of 7 and 6 irrigations were applied to maize, and soybean, respectively (table 1). For sensor-based treatments, the irrigation amounts varied substantially from the conventional treatment. 
Table 1. Irrigation dates and amounts (in $\mathrm{mm}$ ) for the conventional and sensor-based irrigation treatments during 2020 growing season.

\begin{tabular}{|c|c|c|}
\hline \multirow{2}{*}{ Date } & Conventional Treatment & Sensor-Based Treatment \\
\hline & \multicolumn{2}{|c|}{ Maize } \\
\hline $7 / 8 / 2020$ & 30.48 & 15.24 \\
\hline $7 / 14 / 2020$ & 30.48 & 30.48 \\
\hline $7 / 18 / 2020$ & 30.48 & 2.54 \\
\hline $7 / 25 / 2020$ & 30.48 & 15.24 \\
\hline $8 / 3 / 2020$ & 30.48 & 20.32 \\
\hline $8 / 10 / 2020$ & 30.48 & 5.00 \\
\hline $8 / 25 / 2020$ & 30.48 & 15.24 \\
\hline \multirow[t]{2}{*}{ Total } & 213.36 & 104.06 \\
\hline & \multicolumn{2}{|c|}{ Soybean } \\
\hline $7 / 14 / 2020$ & 30.48 & 30.48 \\
\hline $7 / 22 / 2020$ & 30.48 & 30.48 \\
\hline $7 / 29 / 2020$ & 30.48 & 15.24 \\
\hline $8 / 5 / 2020$ & 30.48 & 15.24 \\
\hline $8 / 12 / 2020$ & 30.48 & 2.54 \\
\hline $8 / 27 / 2020$ & 30.48 & 2.54 \\
\hline Total & 152.4 & 96.52 \\
\hline
\end{tabular}

The meteorological measurements were obtained from the High Plains Regional Climate Center's (HPRCC) Automated Weather Data Network for the hourly averaged ambient air temperature and relative humidity (used for determination of VPD), and daily values of precipitation. This station was approximately $1 \mathrm{~km}$ southeast of the research field with sensor heights of $2 \mathrm{~m}$ above ground. The weather data from the Nebraska Mesonet Memphis $5 \mathrm{~N}$ station $\left(41.15^{\circ} \mathrm{N}, 96.417^{\circ} \mathrm{W}\right.$; NSCO) was used (Shulski et al., 2018).

Table 2. The planting date, the observed vegetative and reproductive growth stages dates, and the date of harvest for maize and soybean during

\begin{tabular}{ccccc}
\hline \multicolumn{7}{c}{ 2020 growing season. } \\
\hline Crop & Planting Date & Vegetative Period & Reproductive Period & Date of Harvest \\
\hline Maize & 11 May & 28 May - 16 July & 17 July - 29 September & 16 October \\
\hline Soybean & 1 May & 15 May - 15 July & 16 July - 21 September & 29 September \\
\hline
\end{tabular}

The crop yield was measured using yield monitors installed on the harvesters. Yield Editor Software version 2.0 (Agriculture Research Service, United States Department of Agriculture) was used to filter and clean yield data. The filtered yield was checked by the average yield obtained from the grain carts. The yield analysis was compiled based on the computed dry mass of crop grain yield. The mean yield for each treatment in maize and soybean was determined, and the yield differences were analyzed.

\section{Sensors}

\section{GS-1 soil water sensor}

GS-1 soil water sensor (METER Group Inc., Pullman, WA) is a capacitance and frequency domain technology based sensor with a rugged and durable design. The sensor uses an oscillator running at $70 \mathrm{MHz}$ that charges in response to the dielectric constant of the surrounding material. Through a correlation of the measured dielectric constant to the apparent permittivity, and the permittivity to volumetric soil water content $\left(\theta_{v}, \mathrm{in}^{3} \mathrm{~m}^{-3}\right), \theta_{v}$, is derived from the charge value $\left(V_{\text {charge }}\right.$, in $\mathrm{mV}$ ) provided by the sensor:

$$
\theta_{v}=4.94 \times 10^{-4} \times V_{\text {charge }}-0.554
$$

A datalogger (CR1000, Campbell Scientific, Inc., Logan, Utah) was used to sample at a frequency of $5 \mathrm{~s}$ and record an average $\theta_{v}$ every $15 \mathrm{~min}$.

\section{SI-111 infrared radiometer}

SI-111 infrared radiometer (Apogee Instruments, Inc., Logan, Utah, USA) measures emitted infrared radiation (within an atmospheric window of $8-14 \mu \mathrm{m}$ ) from which target surface temperature is remotely determined. This sensor has a $44^{\circ}$ field of view and $\pm 0.2{ }^{\circ} \mathrm{C}$ accuracy over the temperature range of -10 to $65^{\circ} \mathrm{C}$. The IRTs monitored temperatures of maize and soybean field surfaces continuously. The IRTs were maintained at a height of $1 \mathrm{~m}$ above the canopy throughout the growing season for maize (adjusted every two weeks after tasseling), resulting in a circular horizontal target around 0.513 $\mathrm{m}^{2}$ in size at the top of the canopy. The installation height for soybeans was $2 \mathrm{~m}$ from the ground surface and remained above the canopy at that height at all times. The measured voltage $\left(V_{\text {measured }}, \mathrm{in} \mathrm{mV}\right)$ is related to the temperature of the surface using the manufacturer's calibration:

$$
T_{c}=c_{2} \boldsymbol{X}\left(V_{\text {measured }}\right)^{2}+c_{1} \boldsymbol{X}\left(V_{\text {measured }}\right)-c_{0}
$$

The IRT sensors were calibrated by the manufacturer (Apogee Instruments, Inc.) and re-calibrated (once every two years) based on manufacturer's recommendations. The canopy temperatures $\left(T_{c}\right)$ along with the air temperature $\left(T_{a}\right)$ were measured 
by the datalogger (CR1000, Campbell Scientific, Inc., Logan, Utah) every $5 \mathrm{~s}$ and averaged and recorded at 1 min intervals.

\section{Irrigation Management for sensor-based treatment}

In this study, the irrigation on the sensor-based irrigation treatment was managed by the determined root zone water depletion $\left(D_{r w}\right.$, in $\mathrm{mm}$ ) for the top $1 \mathrm{~m}$ soil profile (Singh et al., 2020) and the crop water stress index (CWSI) for the maize and soybean canopy. The $D_{r w}$ was determined using the difference between the soil field capacity of the soil ( $F C$, in $\mathrm{mm}$ ) and the root zone water depth ( $W D$, in $\mathrm{mm}$; i.e., the equivalent depth of water in the soil and is a function of $\theta_{v}$ and thickness of soil layer). $F C$ was estimated based on the soil texture with a pedotransfer function (Saxton and Rawls, 2006) and the depth of root zone.

$$
\begin{gathered}
D_{r w}=F C-W D \\
W D=\theta_{v(a t 0.15 \mathrm{~m})} \boldsymbol{X} 305 \mathrm{~mm}+\theta_{v(a t 0.46 \mathrm{~m})} \times 305 \mathrm{~mm}+\theta_{v(a t 0.76 \mathrm{~m})} \boldsymbol{X} 390 \mathrm{~mm}
\end{gathered}
$$

The root zone water depth for the top $1 \mathrm{~m}$ soil profile was determined using the depth weighted-average method from the observed $\theta_{v}$ reported by GS- 1 sensors installed at $0.15,0.46$, and $0.76 \mathrm{~m}$ depths for each location. The CWSI within a diurnal period was generally observed during the mid-afternoon, i.e. around 14:00 hours CDT (approximately 2 hours after solar noon), indicating the time of potential maximum $\Delta T$ during the day. Therefore, the analysis was limited to dataset retrieved at 1400 hours, CDT for the non-cloudy/non-precipitation days during 2020 growing season.

The crop water stress index (CWSI) provides an estimate of crop water status with respect to the minimum and maximum levels of stress that can occur due to an excess or deficiency of water. The CWSI non-water stressed and water-stressed baselines for the maize and soybean were determined using an empirical approach with the combined data from the previous growing seasons (Singh et al., 2021). CWSI is the comparison of difference between measured canopy and air temperatures $\left(T_{c}-T_{a}\right.$ or $\left.\Delta T\right)$, and the lower $\left(d T_{L L}\right)$ and upper $\left(d T_{U L}\right)$ limits of canopy-air temperature differential.

$$
C W S I=\frac{\left(\Delta T-d T_{L L}\right)}{\left(d T_{U L}-d T_{L L}\right)}
$$

The lower $\left(d T_{L L}\right)$ and upper $\left(d T_{U L}\right)$ limit values were found under non-water-stressed/irrigated conditions (minimum $\Delta T$ amongst irrigated treatments), and water-stressed/rainfed conditions (maximum $\Delta T$ amongst rainfed treatments), respectively based on the approach by Jackson et al. (1981). The fundamental assumption for the empirical approach is that there is a linear relationship between $\mathrm{dT}_{\mathrm{LL}}$ and vapor pressure deficit $(V P D)$ for a given non-water-stressed crop under a specific climatic condition:

$$
\begin{aligned}
& d T_{L L}=T_{c}-T_{a}=m \boldsymbol{X}(V P D)+b \\
& V P D=((100-R H) / 100) \times\left(\frac{610.7 \times 10^{(7.5 T) /(237.3+T)}}{1000}\right)
\end{aligned}
$$

where " $m$ " and " $b$ " are the slope and intercept of the linear relationship, respectively (Eq. 6). The VPD (kPa) was determined as shown in Eq. 7 from the relative humidity $(R H$, in $\%)$ and the ambient air temperature $\left(T\right.$, in $\left.{ }^{\circ} \mathrm{C}\right)$ values reported by the adjacent Nebraska Mesonet weather station. Based on the pre-determined coefficients for the lower baseline and the upper baseline, the CWSI for maize and soybean were reported at various growth stages (from late vegetative to early maturity) during the 2020 growing season.

Table 3. The coefficients for the lower baseline (non-water stressed) and the constant value for the upper baseline (water-stressed) developed from $\Delta T$ values $\left(T_{\text {canopy }}-T_{\text {air }}\right)$ for maize and soybean during 2018 and 2019 growing seasons (Singh et al., 2021).

\begin{tabular}{cccc}
\hline \multirow{2}{*}{ Crop Type } & \multicolumn{2}{c}{ Coefficients for the lower baseline } & Constant for the upper baseline \\
\cline { 2 - 3 } & $\mathrm{m}$ & $\mathrm{b}$ & $-1.0^{\circ} \mathrm{C}$ \\
\hline Maize & $-1.29^{\circ} \mathrm{C}$ & $-1.10^{\circ} \mathrm{C}$ & $-1.2^{\circ} \mathrm{C}$ \\
\hline Soybean & $-1.35^{\circ} \mathrm{C}$ & $-0.73^{\circ} \mathrm{C}$ & \\
\hline
\end{tabular}

The $C W S I$ and $D_{r w}$ were determined for the sensor node stations installed in maize and soybean. The timing of irrigation for the sensor-based irrigation treatment was based on the reported CWSI. A lower value of CWSI (around zero) would indicate lower stress, and a higher value (around one) would indicate higher stress. The irrigation for the sensor-based treatment was triggered when the CWSI was more than 0.5. In a situation, where the center pivot had to make a revolution for irrigating conventional treatment but the CWSI was less than 0.5, a minimum amount of irrigation $(2.54 \mathrm{~mm})$ was set to be applied for the sensor-based treatment. This was done in order to avoid mechanical issues with the sprinkler set. The amount of irrigation water was determined by the $D_{r w}$ so as to bring the status of the water table sufficiently above MAD.

\section{Data Analysis}

The total prescribed irrigation depth was compared for the sensor-based and conventional treatment. The average yield for the three treatments (sensor-based irrigation, conventional, and rainfed) in maize and soybean were assessed. The irrigation water use efficiency (IWUE) for conventional and sensor-based treatment were computed following Djaman and Irmak (2012) as:

$$
I W U E=\frac{Y_{i}-Y_{d}}{I_{i}}
$$

where IWUE is expressed in $\mathrm{kg} \mathrm{ha}^{-1} \mathrm{~mm}^{-1}, Y$ is dry yield $\left(\mathrm{kg} \mathrm{ha}^{-2}\right)$, and $I$ is applied irrigation depth $(\mathrm{mm})$. The subscripts 
$i$ and $d$ represent variables corresponding to irrigation treatment $i$, and dryland treatment $d$, respectively.

The difference between the yields for the treatments was investigated through Analysis of variance (ANOVA) with a significance level of $\alpha=0.05$, conducted using the statistical computing language $\mathrm{R}$ ( $\mathrm{R}$ version 3.3.2, $\mathrm{R}$ Foundation for Statistical Computing, Wein, Austria). In addition, the difference in the irrigation amounts for sensor-based irrigation treatment and the conventional treatment was assessed. The interaction effect between the irrigation amount and the output yield was determined using the two-way ANOVA. The implications for agricultural water management were also discussed.

\section{RESULTS}

\section{Soil Properties}

The estimates of $F C$ and WP from Bhatti et al. (2020) and Singh et al. (2020) were used for the 2020 growing season. The $F C$ values ranged from 0.37 to $0.45 \mathrm{~m}^{3} \mathrm{~m}^{-3}$ for the north half and from 0.38 to $0.44 \mathrm{~m}^{3} \mathrm{~m}^{-3}$ for the south half. The range of $W P$ values was from 0.17 to $0.21 \mathrm{~m}^{3} \mathrm{~m}^{-3}$ for the north and from 0.18 to $0.20 \mathrm{~m}^{3} \mathrm{~m}^{-3}$ for the south. The values of $F C$ and $W P$ were helpful in the determination of $A W C$ and $M A D$ values for the north and south halves.

\section{Variability in Root Zone Depletion and Crop Water Stress Index}

The responses from the stationary sensor node stations installed in the maize and soybean were observed. The variability in the soil water content was highlighted by the differing root zone water depletion $\left(D_{r w}\right)$ for the top $1 \mathrm{~m}$ profile in the maize and soybean throughout the growing season (Fig. 3). The soil profile was near full level (above or close to $F C$ ) at the beginning of the growing season, which is typical for a field in eastern Nebraska. The cumulative precipitation for months May to October as recorded by the adjacent weather station was $260 \mathrm{~mm}$ during 2020 growing season. Effective precipitation $\left(P_{e f f}\right)$ which is the difference between the intercepted precipitation and the runoff has been indicated in the figure 3 . The management allowable depletion $(M A D)$ value was calculated as the average of total available water $(T A W)$ and the $F C$. The sensor-based irrigation treatment plots were prescribed with a total gross irrigation of 101.5 , and $91.4 \mathrm{~mm}$, for maize, and soybean respectively during the growing season. The amount of irrigation to be applied in maize and soybean was decided based on the observed $D_{r w}$ at the sensor node station. The irrigation amount was kept consistent amongst the six and twelve replications in maize and soybean, respectively during the 2020 growing season. The decline in $W D$ for soybean after August 28,2020 was due to lack of precipitation toward the end of the growing season along with no irrigation. During this period of time, majority of the soybean was at R5 growth stage where the soil water extraction is lower and sensitivity to water stress is less. So, an additional irrigation beyond that point was not applied for soybean. However, the irrigation amount applied for maize after the R4 growth stage was minimal as there was enough water in the soil profile to meet the crop water requirements until physiological maturity.

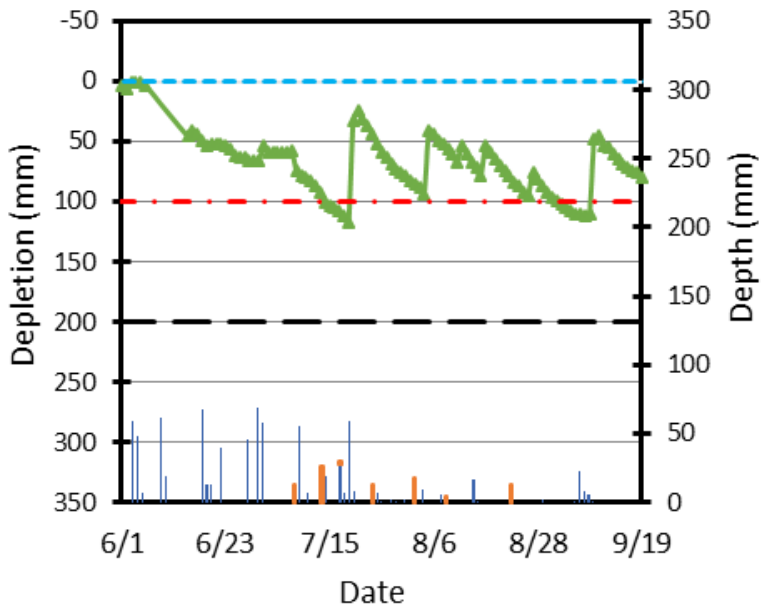

(a)

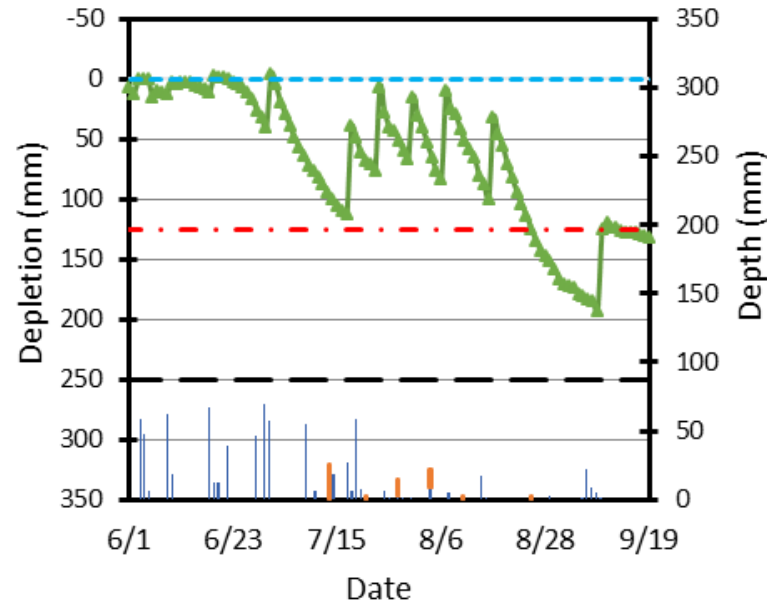

(b)

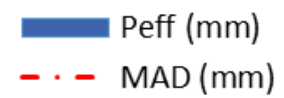

Net Irrigation $(\mathrm{mm})$
- - Total Available Water $(\mathrm{mm})$

$\longrightarrow$ Root Zone Depletion ( $\mathrm{mm})$

---- Field Capacity ( $\mathrm{mm})$

Figure 3. Root zone soil water depletion (in $\mathrm{mm}$ ) for maize (a) and soybean (b) along with total available water ( $\mathrm{mm}$ ), field capacity (mm), management allowable depletion $(\mathrm{mm})$, net irrigation $(\mathrm{mm})$, and effective precipitation $(\mathrm{mm})$ for the 2020 growing season.

The lower (non-stressed) and upper (stressed) baselines were measured for maize and soybean during 2018 and 2019 growing seasons. Consequently, the $C W S I$ values were calculated using these baselines relating the difference between canopy $\left(T_{c}\right)$ and air $\left(T_{a}\right)$ temperatures to the vapor pressure deficit $(V P D, \mathrm{kPa})$ as outlined by Idso et al. (1981). When the 
CWSI values for maize and soybean were plotted against the time, synchronous patterns with irrigation and precipitation events were observed (Fig. 4). The CWSI values generally dropped to a lower value following each wetting event, then steadily increased to a higher value. The CWSI values were determined a few days before the irrigation applications to decide for the timing of irrigation application. A higher value of CWSI indicated crop water stress and irrigation application was triggered by looking at the crop physiological stage and higher values of CWSI. The six irrigation application events were scheduled between V12 - R4 growth stages for maize and between V12 - R5 for soybean, as this phase was the most active soil-water extraction period and the most sensitive stages to water stress. Due to only $67 \mathrm{~mm}$ of precipitation during this period, the effect of amount and timing of irrigation management (sensor-based vs conventional) was most prominent. Minimal irrigation applications $(2.54 \mathrm{~mm})$ were applied to soybean following R4 growth stage.
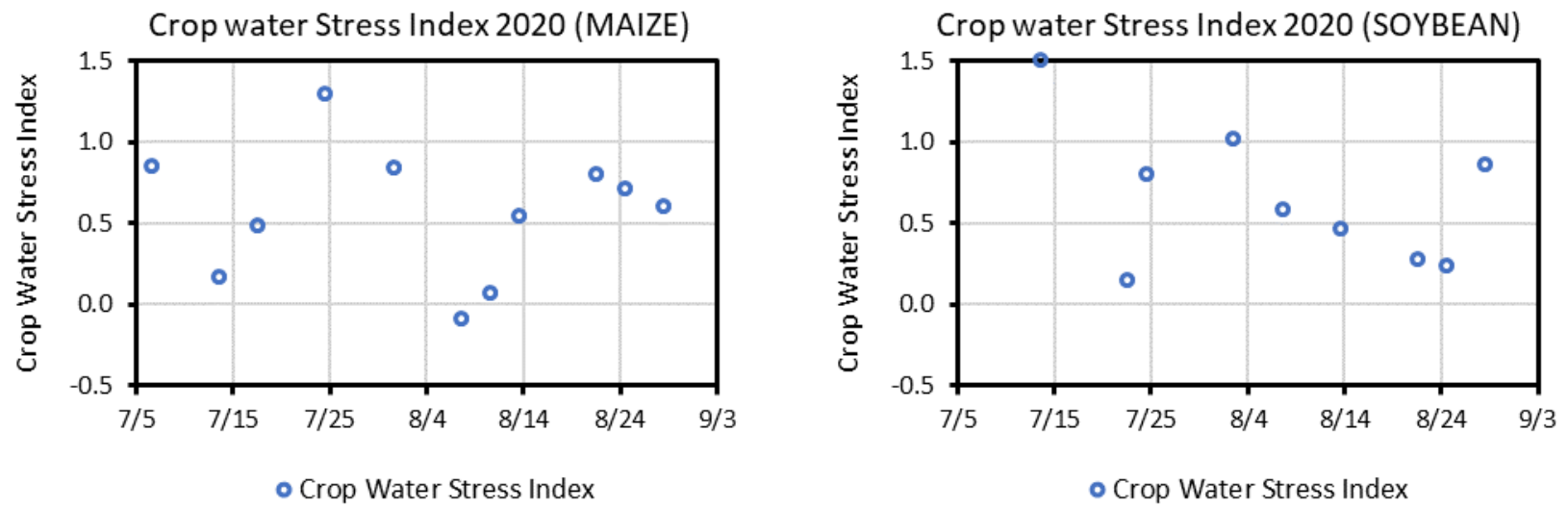

Figure 4. The reported crop water stress index (CWSI) for maize and soybean during 2020 growing season.

\section{Treatment effects on maize and soybean yield}

To understand how different irrigation treatments affect yield under sensor-based and conventional treatments for maize and soybean, the irrigation amounts $(\mathrm{mm}$ ), yield outputs (Mega grams per hectare, $\mathrm{Mg} / \mathrm{ha}$ ), and the irrigation water use efficiency $(I W U E, \mathrm{~kg} / \mathrm{ha} / \mathrm{mm})$ were compared. In the sensor-based treatment, irrigation was managed based on $D_{r w}$ and $C W S I$; hence, most parts of the field were sufficiently irrigated to prevent yield reduction. The results of the tests for the 2020 growing season are discussed below.

Individual univariate ANOVA for maize and soybean were performed to study differences in yield for the three treatments. The effects were tested at a $5 \%$ level of significance. Overall, the treatment had a significant effect on yield for maize $(\mathrm{p}$-value $=0.0278)$ and soybean $(\mathrm{p}$-value $=0.0151)$.

Table 4. The reported degrees of freedom (DF), mean irrigation (mm), yield (Mg/ha), and irrigation water use efficiency (IWUE, Mg /ha/mm) for various treatments (sensor-based irrigation, conventional, and rainfed) in maize and soybean during 2020 growing season.

\begin{tabular}{|c|c|c|c|c|}
\hline Treatment & DF & Mean Irrigation (mm) & Yield (Mg/ha) & IWUE $(\mathrm{kg} / \mathrm{ha} / \mathrm{mm})$ \\
\hline \multicolumn{5}{|c|}{ Maize } \\
\hline Sensor-based & 6 & 101.5 & $13.32 \pm 0.98^{*}$ & 17.35 \\
\hline Conventional & 6 & 213.4 & $13.32 \pm 0.60$ & 8.29 \\
\hline Rainfed & 6 & 0 & $11.56 \pm 0.88$ & - \\
\hline \multicolumn{5}{|c|}{ Soybean } \\
\hline Sensor-based & 12 & 91.4 & $4.60 \pm 0.39^{*}$ & 3.93 \\
\hline Conventional & 12 & 152.4 & $4.72 \pm 0.40$ & 3.09 \\
\hline Rainfed & 12 & 0 & $4.24 \pm 0.38$ & - \\
\hline
\end{tabular}

'*' denotes that mean yield for the sensor-based treatment is significantly different ( $\mathrm{p}$-value $>0.05$ ) than the mean yield for the rainfed treatment but not conventional treatment.

The summary of estimated least square means from the ANOVAs for various variables in each treatment for maize and soybean during 2020 growing season have been summarized by table 5. For maize in 2020, the mean yield ranged from $10.52-14.76 \mathrm{Mg} \mathrm{ha}^{-1}$. The minimum and maximum yield for soybean was 3.79 and $5.39 \mathrm{Mg} \mathrm{ha}^{-1}$, respectively. The minimum yield for maize and soybean was observed in one of the rainfed plots. A two-tailed hypothesis T-test for two independent means with significance level of 0.05 was performed to investigate the difference in yields for different treatments. Significant differences in the maize and soybean yield were found among treatments. For maize, the observed yield for the rainfed treatment was significantly different than the conventional ( $\mathrm{p}$-value $=0.0011)$ and the sensor-based $(\mathrm{p}-$ value $=0.0042)$ treatments. However, the observed yields for conventional and sensor-based treatments were not significantly different ( $\mathrm{p}$-value $=0.4933$ ) for maize. The observed yield for rainfed treatment was significantly different than the sensor-based $(\mathrm{p}$-value $=0.0160)$ and the conventional $(\mathrm{p}$-value $=0.0037)$ treatments for the soybean. On the contrary, no significant difference was observed between the sensor-based treatment and the conventional treatment $(\mathrm{p}$-value $=$ 0.2483). A two-way ANOVA test was performed to analyze the interaction effect between the mean irrigation application 
and the observed yield for the sensor-based treatment and the conventional treatment. For soybean, there is significant interaction effect between the amount of irrigation and the observed yield for conventional ( $p$-value $<0.0001)$ and sensorbased (p-value < 0.0001) treatments, and a significant difference between the treatments was also observed (p-value < 0.0001). Similarly, a significant interaction effect between the amount of irrigation and the observed yield for conventional (p-value < 0.0001) and sensor-based (p-value < 0.0001) treatments was observed, and the difference between the treatments was significant (p-value < 0.0001). The irrigation water use efficiency (IWUE) values for the maize and soybean varied from 5 to $32 \mathrm{~kg} \mathrm{ha}^{-1} \mathrm{~mm}^{-1}$, and -2 to $12 \mathrm{~kg} \mathrm{ha}^{-1} \mathrm{~mm}^{-1}$, respectively across all irrigated (sensor-based and conventional) treatments during the one-year study period.

\section{DISCUSSION}

The maize and soybean crop response being similar (if not better) between the sensor-based treatment and the conventional treatment (as managed by a common producer) demonstrate a positive result for sensor-based irrigation management. This method of plant and soil water sensing feedback requires minimal labor and cost depending on the number of sensors to be installed. Irrigation management based on plant and soil water sensing feedback is being investigated extensively by researchers recently (Andrade et al., 2015, 2020; Evett et al., 2020b; O'Shaughnessy et al., 2020a; Stone et al., 2020; Vories et al., 2020). In our study, the amount of the irrigation application was based on soil water sensing feedback (i.e., $D_{r w}$ ), and timing was managed based on the observed plant feedback (i.e., $C W S I$ ) for maize and soybean. The sensorbased irrigation management system is functional and produced significantly higher yields than the rainfed plots for maize and soybean. In addition, the observed yields were not significantly different from the conventional treatment, and the water application amounts were significantly lower for sensor-based treatments. However, the sensor-based irrigation management could be continuously improved.

The IWUE values for the sensor-based treatment and conventional treatments in maize and soybean during the study period were generally close in magnitude. The difference in $I W U E$ for the sensor-based and conventional treatments was higher in maize than soybean. The $I W U E$ values ranging from 12 to $35 \mathrm{~kg} \mathrm{ha}^{-1} \mathrm{~mm}^{-1}$ under center pivots in Nebraska were reported by Gonçalves et al. (2020). In a previous study at this site, Barker et al. (2018) reported IWUE values ranging from 5.5 to $22.7 \mathrm{~kg} \mathrm{ha}^{-1} \mathrm{~mm}^{-1}$ for maize, and values ranging from -5.1 to -3.0 for soybean during a wetter than normal growing season (2016). The IWUE values for maize as reported by Stone et al. (2020) were within -18 to $32 \mathrm{~kg} \mathrm{ha}^{-1} \mathrm{~mm}^{-1}$ in South Carolina. The IWUE is highly dependent on climatic variability (i.e., the extent of the hot and dry weather), which causes variability in rainfed yields for different years. A larger value of $I W U E$ may indicate a drier year, as the irrigation would have a larger impact on the yield in comparison to a wetter year. The determination of IWUE is simple and more commonly used in comparison to the additional terms such as crop water use efficiency (CWUE) and evapotranspiration water use efficiency $(E T W U E)$ because it does not involve the challenging part of calculating actual crop evapotranspiration $\left(E T_{a}\right)$. However, accounting for $E T_{a}$ may reflect a complete assessment of water productivity because: (i) not all irrigation water applied is used for $E T_{a}$, as partial amount of water may be lost to deep percolation and/or runoff, and (ii) stored soil water at planting and rainfall from planting to late maturity may also contribute to $E T_{a}$. Therefore, $C W U E$ and $E T W U E$ could potentially quantify the efficiency of a crop production system as they directly reflect the amount of grain yield produced per amount of water used, rather than per depth of water applied. While using IWUE, the precipitation/rainfall amounts should be accounted for to more accurately demonstrate the impact of irrigation on crop water productivity.

The use of $D_{r w}$ and CWSI could be a powerful tool to monitor and quantify water stress. The current study focuses on managing irrigation based on the observed $D_{r w}$ and CWSI collaboratively. The results from O'Shaughnessy et al. (2020a) demonstrated that using the plant feedback alone with a single thermal stress threshold for irrigation management produced significantly lower yields in comparison to the manual irrigation management techniques for sorghum. However, the hybrid feedback method that used the combination of plant and soil water sensing feedback for irrigation management produced grain yields that were significantly greater than the plant feedback and manual irrigation scheduling methods. Similar results were observed in our study for maize and soybean, as we used the plant and soil water sensing feedback for the sensor-based irrigation during 2020 growing season for maize and soybean that led to notable decrease in the amount of water used for irrigation as compared to the conventional treatment. However, the yield produced was similar to the conventional treatment. Future studies are required to investigate the performance of the upgraded plant and soil water sensing feedback system for maize and soybean production in Nebraska.

\section{CONCLUSION}

A field experiment was conducted in a sub-humid climate of East-Central Nebraska during the 2020 growing season over maize and soybean to investigate a decision support system based on soil water and plant feedback using uniform irrigation management. The yields from the sensor-based treatment that used the decision support system were compared to the conventional treatment (managed by a professional crop consultant) and the rainfed (no-irrigation) treatment in maize and soybean. The soil water feedback was informed from the determination of $D_{r w}$ (for top $1 \mathrm{~m}$ profile) by the soil water content sensors. The soil water content sensors were calibrated for the soil type at the research farm previously. The plant feedback 
was informed from the determination of CWSI by the IRT sensors. The non-water stressed and water stressed baselines for the quantification of CWSI were developed during 2018 and 2019 growing seasons. It was observed that each treatment had a significant effect on the yield for maize and soybean. The mean yield ranged within $10.52-14.76 \mathrm{Mg} \mathrm{ha}^{-1}$, and $3.79-$ $5.39 \mathrm{Mg} \mathrm{ha}^{-1}$, for maize, and soybean, respectively. The observed yield for the rainfed treatment was significantly different from the sensor-based treatment and the conventional treatment in maize and soybean. However, the observed yields for sensor-based treatment and conventional treatment were not significantly different in maize and soybean. The interaction effect between the mean irrigation application and the observed yield for the sensor-based treatment and the conventional treatment was performed. It was found out that there was a significant interaction effect between the yield and irrigation application for maize and soybean in sensor-based and conventional treatments. The results from this study indicate that the application of $D_{r w}$ and $C W S I$ could be a powerful tool to monitor and quantify water stress continuously. The determination of soil water $\left(D_{r w}\right)$ and plant $(C W S I)$ feedback could potentially better inform the decision support system for uniform irrigation management. The authors recommend future studies aiming to investigate this decision support system is effective for uniform irrigation scheduling of other crops and at different locations in this region.

\section{Acknowledgements}

The funding for this research was provided by a grant from the USDA NIFA Agricultural and Food Research Initiative (Award Number 2017-67021-26249) and Graduate Student Support from the Robert B. Daugherty Water for Food Global Institute at the University of Nebraska. Additional support was received from the Hatch Act (USDA NIFA, Accession Number 1009760) and the Department of Biological Systems Engineering at the University of Nebraska-Lincoln. The authors thank Dr. Burdette Barker for input in the experimental design; Alan L. Boldt, Eric Wilkening, and Suresh Pradhyun Kashyap for assistance with the data collection; Mr. Mark Schroeder and his team from the University of Nebraska's Eastern Nebraska Research and Extension Center for their cooperation and help with field operations. Weather data were provided by the Nebraska Mesonet and the Nebraska State Climate Office through the High Plains Regional Climate Center.

\section{Conflict of Interest Statement}

The mention of trade names or commercial products is for the information of the reader and does not constitute an endorsement or recommendation for use by the University of Nebraska-Lincoln or the authors. The authors declare no conflict of interest.

\section{REFERENCES}

Adeyemi, O., Grove, I., Peets, S., Norton, T. (2017). Advanced monitoring and management systems for improving sustainability in precision irrigation. Sustainability (Switzerland), 9(3), 1-29. https://doi.org/10.3390/su9030353

Andrade, M. A., O’Shaughnessy, S. A., Evett, S. R. (2015). ARSmartPivot v.1-Sensor based management software for center pivot irrigation systems. American Society of Agricultural and Biological Engineers Annual International Meeting 2015, 3(i), 2329-2346. https://doi.org/10.13031/aim.20152188736

Andrade, M. A., O’Shaughnessy, S. A., Evett, S. R. (2020). ARSPivot, A Sensor-Based Decision Support Software for Variable-Rate Irrigation Center Pivot Systems: Part A. Development. Transactions of the ASABE, 63(5), $1521-1533$.

Barker, J. B., Heeren, D. M., Daugherty, R. B., Neale, C. M. U., Rudnick, D. R. (2018). Evaluation of variable rate irrigation using a remote-sensing-based model. Agricultural Water Management, $203, \quad 63-74$. https://doi.org/10.1016/j.agwat.2018.02.022

Bhatti, S., Heeren, D. M., Barker, J. B., Neale, C. M. U., Woldt, W. E., Maguire, M. S., Rudnick, D. R. (2020). Site-specific irrigation management in a sub-humid climate using a spatial evapotranspiration model with satellite and airborne imagery. Agricultural Water Management, 230(May 2019), 1-13. https://doi.org/10.1016/j.agwat.2019.105950

Datta, S., Taghvaeian, S., Ochsner, T. E., Moriasi, D., Gowda, P., Steiner, J. L. (2018). Performance assessment of five different soil moisture sensors under irrigated field conditions in Oklahoma. Sensors (Switzerland), 18(11), 1-17. https://doi.org/10.3390/s18113786

DeJonge, K. C., Taghvaeian, S., Trout, T. J., Comas, L. H. (2015). Comparison of canopy temperature-based water stress indices for maize. Agricultural Water Management, 156, 51-62. https://doi.org/10.1016/j.agwat.2015.03.023

Djaman, K., Irmak, S. (2012). Soil Water Extraction Patterns and Crop, Irrigation, and Evapotranspiration Water Use Efficiency of Maize under Full and Limited Irrigation and Rainfed Settings. Transactions of the ASABE, 55(4), 12231238. Retrieved from https://doi.org/10.13031/2013.42262

Eisenhauer, D. E., Martin, D. L., Heeren, D. M., Hoffman, G. J. (2021). Irrigation Systems Managament (in press). (D. M. Heeren, Ed.). St. Joseph, Michigan: American Society of Agricultural and Biological Engineers. 
Evett, S. R., Colaizzi, P. D., Lamm, F. R., O’Shaughnessy, S. A., Heeren, D. M., Trout, T. J., ... Lin, X. (2020). Past, Present, and Future of Irrigation on the U.S. Great Plains. Transactions of the ASABE, 63(3), 703-729. Retrieved from https://doi.org/10.13031/trans.13620

Evett, S. R., O’Shaughnessy, S. A., Andrade, M. A., Colaizzi, P. D., Schwartz, R. C., Schomberg, H. S., ... Sui, R. (2020). Theory and Development of a VRI Decision Support System: The USDA-ARS ISSCADA Approach. Transactions of the ASABE, 63(5), 1507-1519. Retrieved from https://doi.org/10.13031/trans.13922

Evett, S. R., O’Shaughnessy, S. A., Peters, R. T. (2014). Irrigation scheduling and supervisory control and data acquisition system for moving and static irrigation systems. US Patent 8,924,031. Retrieved from https://patents.google.com/patent/US8924031B1/en

Evett, S. R., Parkin, G. W. (2005). Advances in Soil Water Content Sensing: The Continuing Maturation of Technology and Theory. Vadose Zone Journal, 4(4), 986-991. https://doi.org/10.2136/vzj2005.0099

Gardner, B. R., Nielsen, D. C., Shock, C. C. (1992). Infrared Thermometry and the Crop Water Stress Index. II. Sampling procedures and interpretation. Journal of Production Agriculture, 5(4), 466-475. Retrieved from https://doi.org/10.2134/jpa1992.0466

Gonçalves, I. Z., Mekonnen, M. M., Neale, C. M. U., Campos, I., Neale, M. R. (2020). Temporal and spatial variations of irrigation water use for commercial corn fields in Central Nebraska. Agricultural Water Management, 228(November). https://doi.org/10.1016/j.agwat.2019.105924

Harun, A. N., Kassim, M. R. M., Mat, I., Ramli, S. S. (2015). Precision irrigation using Wireless Sensor Network. In 2015 International Conference on Smart Sensors and Application, ICSSA 2015 (pp. 71-75). https://doi.org/10.1109/ICSSA.2015.7322513

Idso, S. B., Jackson, R. D., Pinter, P. J., Reginato, R. J., Hatfield, J. L. (1981). Normalizing the stress-degree-day parameter for environmental variability. Agricultural Meteorology, 24(C), 45-55. https://doi.org/10.1016/0002-1571(81)900327

Irmak, S., Haman, D. Z., Bastug, R. (2000). Determination of crop water stress index for irrigation timing and yield estimation of corn. Agronomy Journal, 92(6), 1221-1227. https://doi.org/10.2134/agronj2000.9261221x

Jackson, R. D., Idso, S. B., Reginato, R. J., Pinter, P. J. (1981). Canopy temperature as a crop water stress indicator. Water Resources Research, 17(4), 1133-1138. https://doi.org/10.1029/WR017i004p01133

Kamienski, C., Soininen, J. P., Taumberger, M., Dantas, R., Toscano, A., Cinotti, T. S., .. Neto, A. T. (2019). Smart water management platform: IoT-based precision irrigation for agriculture. Sensors, 19(2). https://doi.org/10.3390/s19020276

Khriji, S., El Houssaini, D., Jmal, M. W., Viehweger, C., Abid, M., Kanoun, O. (2014). Precision irrigation based on wireless sensor network. IET Science, Measurement and Technology, 8(3), 98-106. https://doi.org/10.1049/iet-smt.2013.0137

Lea-Cox, J. D., Williams, J., Mellano, M. A. (2018). Optimising a sensor-based irrigation protocol for a large-scale cutflower operation in southern California. Acta Horticulturae, 1197, 219-225. https://doi.org/10.17660/ActaHortic.2018.1197.29

Lobell, D. B., Cassman, K. G., Field, C. B. (2009). Crop yield gaps: Their importance, magnitudes, and causes. Annual Review of Environment and Resources, 34, 179-204. https://doi.org/10.1146/annurev.environ.041008.093740

Miller, K. A., Luck, J. D., Heeren, D. M., Lo, T., Martin, D. L., Barker, J. B. (2017). A geospatial variable rate irrigation control scenario evaluation methodology based on mining root zone available water capacity. Precision Agriculture, 19(4), 666-683. https://doi.org/10.1007/s11119-017-9548-z

O’Shaughnessy, S. A., Andrade, M. A., Colaizzi, P. D., Workneh, F., Rush, C. M., Evett, S. R., Kim, M. (2020). Irrigation Managment of Potatoes using Sensor Feedback: Texas High Plains. Transactions of the ASABE, 63(5), 1259-1276. Retrieved from https://doi.org/10.13031/trans.13925

O'Shaughnessy, S. A., Andrade, M. A., Evett, S. R. (2017). Using an integrated crop water stress index for irrigation scheduling of two corn hybrids in a semi-arid region. Irrigation Science, 35(5), 451-467. https://doi.org/10.1007/s00271-017-0552-x

O'Shaughnessy, S. A., Kim, M., Andrade, M. A., Colaizzi, P. D., Evett, S. R. (2020). Site-specific irrigation of grain sorghum using plant and soil water sensing feedback - Texas High Plains. Agricultural Water Management, 240(June). https://doi.org/10.1016/j.agwat.2020.106273

Peters, R. T., Evett, S. R. (2008). Automation of a Center Pivot Using the Temperature-Time- Threshold Method of Irrigation Scheduling. Journal of Irrigation and Drainage Engineering, 134(3)(MAY), $286-291$. https://doi.org/10.1061/ASCE_0733-9437(2008)_134:3(286)

Saxton, K. E., Rawls, W. J. (2006). Soil Water Characteristic Estimates by Texture and Organic Matter for Hydrologic Solutions. Soil Science Society of America Journal, 70(5), 1569-1578. https://doi.org/10.2136/sssaj2005.0117 
Schaible, G., Aillery, M. (2012). Water Conservation in Irrigated Agriculture: Trends and Challenges in the Face of Emerging Demands. Economic Information Bulletin. https://doi.org/10.2139/ssrn.2186555

Singh, J., Ge, Y., Heeren, D. M., Walter-shea, E., Neale, C. M. U., Irmak, S., ... Maguire, M. S. (2021). Inter-Relationships between Water Depletion and Temperature Differential in Row Crop Canopies in a Sub-Humid Climate. Agricultural Water Management (under Review).

Singh, J., Heeren, D. M., Rudnick, D. R., Woldt, W. E., Bai, G., Ge, Y., Luck, J. D. (2020). Soil Structure and Texture Effects on the Precision of Soil Water Content Measurements with a Capacitance based Electromagentic Sensor. Transactions of the ASABE, 63(1), 141-152. https://doi.org/10.13031/trans.13496

Singh, J., Lo, T., Rudnick, D. R., Dorr, T. J., Burr, C. A., Werle, R., ... Muñoz-Arriola, F. (2018). Performance assessment of factory and field calibrations for electromagnetic sensors in a loam soil. Agricultural Water Management, 196, 8798. https://doi.org/10.1016/j.agwat.2017.10.020

Soil Survey Staff, 2020. (2020). U.S. Department of Agriculture Natural Resources Conservation Service. Retrieved June 29, 2020, from http://websoilsurvey.sc.egov.usda.gov/

Steward, D. R., Allen, A. J. (2016). Peak groundwater depletion in the High Plains Aquifer, projections from 1930 to 2110. Agricultural Water Management, 170, 36-48. https://doi.org/10.1016/j.agwat.2015.10.003

Stone, K. C., Bauer, P. J., O’Shaughnessy, S. A., Andrade-Rodriguez, A., Evett, S. (2020). A Variable-Rate Irrigation Decision Support System for Corn in the U.S. Eastern Coastal Plain. Transactions of the ASABE, 63(5), 1295-1303. Retrieved from https://doi.org/10.13031/trans.13965

Sui, R. (2017). Irrigation Scheduling Using Soil Moisture Sensors. Journal of Agricultural Science, 10(1), 1. https://doi.org/10.5539/jas.v10n1p1

USDA NASS. (2018). Irrigation and Water Management Survey (2017 Census of Agriculture). Retrieved from https://www.nass.usda.gov/Publications/Highlights/2019/2017Census_Irrigation_and_WaterManagement.pdf

Vories, E., O'Shaughnessy, S., Sudduth, K., Evett, S., Andrade, M., Drummond, S. (2020). Comparison of precision and conventional irrigation management of cotton and impact of soil texture. Precision Agriculture, 22(2), 414-431. https://doi.org/10.1007/s11119-020-09741-3 